\title{
OCCURRENCE OF PESTICIDE RESIDUES IN FOUR STREAMS DRAINING DIFFERENT LAND-USE AREAS IN PENNSYLVANIA
}

U.S. GEOLOGICAL SURVEY

Water Resources Investigations 6-75

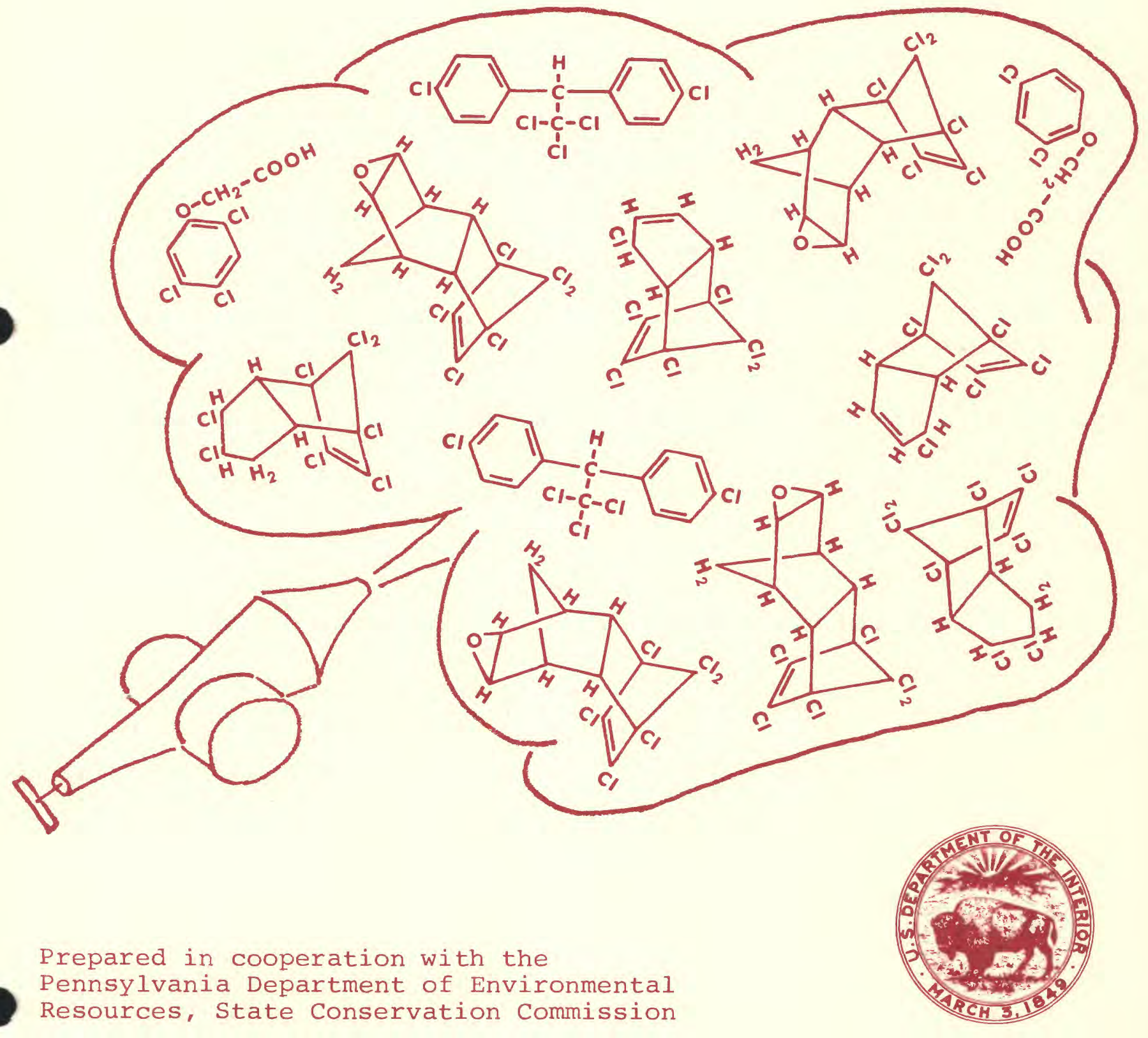




\begin{tabular}{l}
$\begin{array}{l}\text { BIBLIOGRAPHIC DATA } \\
\text { SHEET }\end{array}$ \\
\hline
\end{tabular}

4. Title and Subtitle

OCCURRENCE OF PESTICIDE RESIDUES IN FOUR STREAMS

DRAINING DIFFERENT LAND-USE AREAS IN PENNSYLVANIA

\section{Author(s)}

John F. Truhlar and Lloyd A. Reed

9. Performing Organization Name and Address

U.S. Geological Survey, Water Resources Division

228 Walnut Street

Harrisburg, Pennsylvania 17108

12. Sponsoring Organization Name and Address

U.S. Geological Survey, Water Resources Division

228 Walnut Street

Harrisburg, Pennsylvania 17108

2.

3. Recipient's Accession No.

5. Report Date

June 1975

6.

8. Performing Organization Rept. No. USGS/WRI-6-75

10. Project/Task/Work Unit No.

11. Contract/Grant No.

13. Type of Report \& Period Covered

Fina1

14.

15. Supplementary Notes

Prepared in cooperation with the Pennsylvania Department of

Environmental Resources, State Conservation Commission

16. Abstracts Samples of water, bed material, fish, and soil were collected in four small drainage basins in Pennsylvania in 1969-71 and analyzed to determine the concentrations of chlorinated-hydrocarbon insecticides. Water samples only were also analyzed for phenoxy-acid herbicides. Each basin studied represents a predominant land-use classification--forested, general farming, residential, and orchard farming. A11 water and fish samples showed pesticide concentrations less than the U.S. Public Health Service's (1969) recommended maximum permissible concentration. However, no fish were found in the orchard area stream at the time collection was attempted. DDT or one of its metabolites was the most frequently occurring insecticide and was detected in all media sampled except the forested-area soil. The highest observed combined concentration of DDT and its metabolites in storm-runoff samples was 11.4 micrograms per 1itre in a sample collected from the residential area stream, but the median was higher (0.12 microgram per 1itre) in the orchard area than in the residential area (0.02 microgram per litre).

17. Key Words and Document Analysis. 17a. Descriptors

Pesticides, insecticides, herbicides, *chlorinated-hydrocarbon pesticides,

*pesticide residues, pesticide kinetics, water pollution sources, environmental

sanitation, public health, Pennsylvania.

17b. Identifiers/Open-Ended Terms

*Pesticide-sediment correlation, Susquehanna River basin.

17c. COSATI Field/Group

18. Availability Statement

No restriction on distribution

19. Security Class (This Report) UNCLASSIEIED 20. Security Class (This Page

22. Price USCOMM.DC 8265 -P74 
OCCURRENCE OF PESTICIDE RESIDUES IN FOUR

STREAMS DRAINING DIFFERENT LAND-USE AREAS

IN PENNSYLVANIA

By John F. Truhlar and Lloyd A. Reed

U.S. GEOLOGICAL SURVEY

Water-Resources Investigations 6-75

Prepared in cooperation with

Pennsylvania Department of Environmental

Resources, State Conservation Commission 


\section{UNITED STATES DEPARTMENT OF THE INTERIOR}

Rogers C. B. Morton, Secretary

GEOLOGICAL SURVEY

V. E. McKelvey, Director

For additional information write to:

U.S. Geological Survey

4th Floor, Federal Building

P.0. Box 1107

Harrisburg, Pennsylvania 17108 


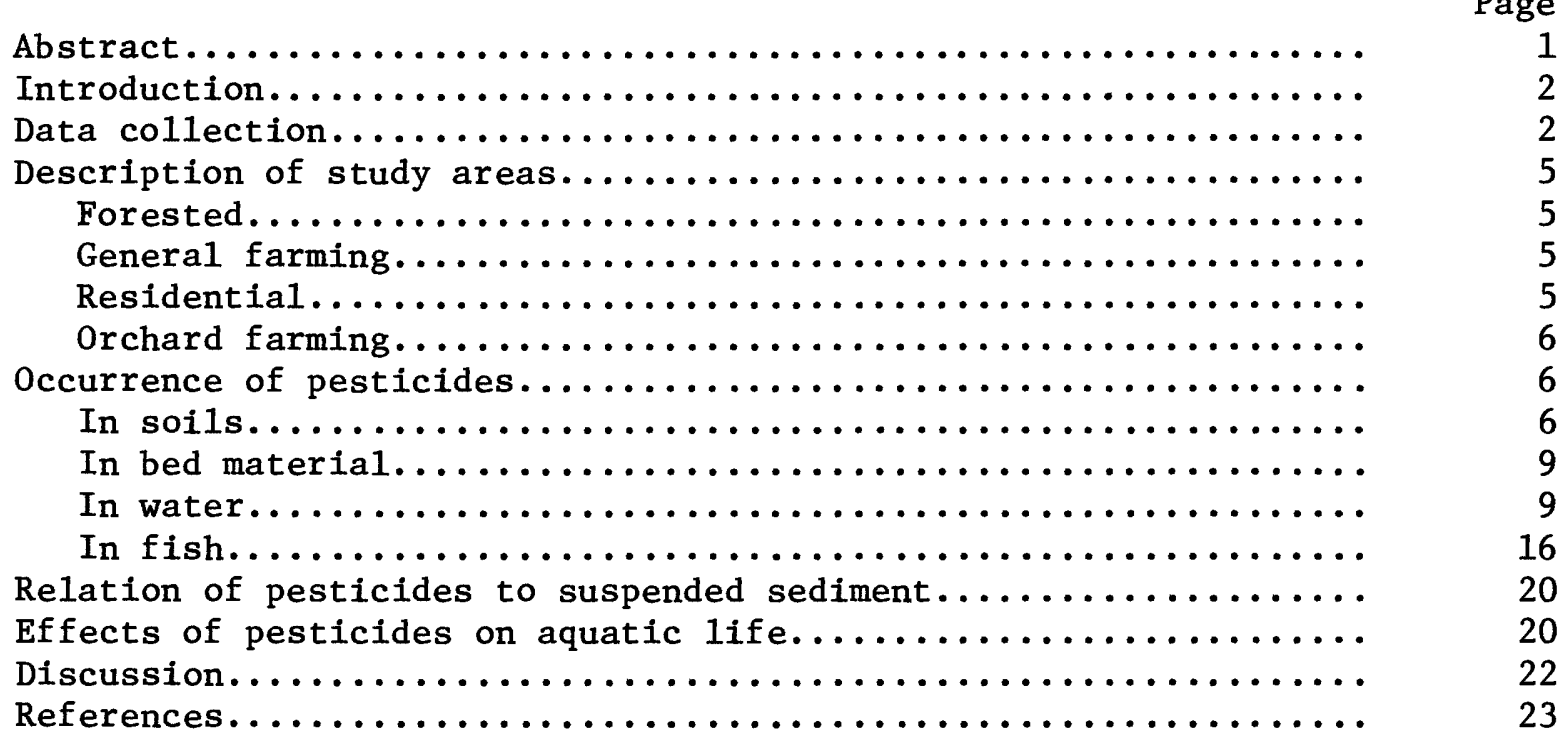

ILLUSTRATIONS

Figure 1. Map showing locations of areas sampled for pesticides..

2. Diagrams showing occurrence of insecticides in soil, bed-material, water, and fish samples............ 3-5. Graphs showing:

3. Range in concentration of DDT and its metabolites

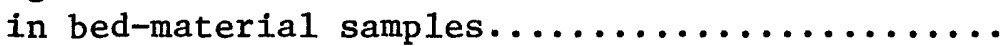

4. Range in concentration of DDT and its metabolites

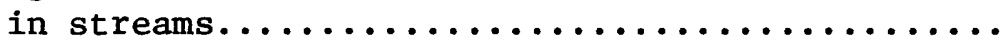

5. Correlation between suspended-sediment concentration and combined concentration of DDT and its metabolites in Latimore Creek tributary..... 


\section{TABLES}

Table 1. Insecticide residues in soil samples collected in stream basins draining different land-use areas..............

Page from streams draining different land-use areas......... 10

3. Pesticide residues in streams draining different land-

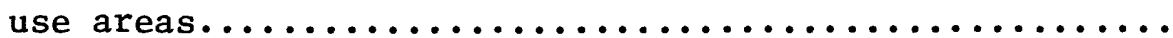

4. Recommended maximum permissible pesticide concentrations in drinking-water supplies, U.S. Public Health Service..

5. Pesticide residues in fish samples collected from streams draining different land-use areas.................

FACTORS FOR CONVERTING ENGLISH UNITS TO INTERNATIONAL SYSTEM (SI) UNITS

English

Inches (in)

Acre

Square miles ( $\mathrm{mi}^{2}$ )

Cubic feet per second $\left(f t^{3 / s}\right)$
Multiply by

Metric

25.4

.4047

2.590

.02832
Millimetres (mm)

Hectare (ha)

Square kilometres $\left(\mathrm{km}^{2}\right)$

Cubic metres per second $\left(\mathrm{m}^{3} / \mathrm{s}\right)$ 


\section{ABSTRACT}

Samples of water, bed material, fish, and soil were collected in four small drainage basins in Pennsylvania in 1969-71 and analyzed to determine the concentrations of chlorinated-hydrocarbon insecticides. Water samples only were also analyzed for phenoxy-acid herbicides. Each basin studied represents a predominant land-use classification--forested, general farming, residential, and orchard farming.

All water and fish samples showed pesticide concentrations less than the U.S. Public Health Service's (1969) recommended maximum permissible concentration. However, no fish were found in the orchard area stream at the time collection was attempted.

DDT or one of its metabolites was the most frequently occurring insecticide and was detected in all media sampled except the forestedarea soil. The highest observed combined concentration of DDT and its metabolites in storm-runoff samples was 11.4 micrograms per litre in a sample collected from the residential area stream, but the median was higher (0.12 microgram per litre) in the orchard area than in the residential area (0.02 microgram per litre).

A sample of the top 0.5 inch (13 millimetres) of orchard soil contained 40,000 micrograms per kilogram of DDT and its metabolites, even though DDT had not been used in the orchards for several years prior to this study. Maximum concentrations detected in other orchard media are 330 micrograms per kilogram in bed material and 3.45 micrograms per litre in storm runoff.

Dieldrin was the second most frequently occurring insecticide. Other insecticides detected were chlordane, heptachlor epoxide, lindane, and a trace of aldrin in one fish sample. At least one of the following herbicides--2,4-D, silvex, or 2,4,5-T--was detected in each stream. 


\section{INTRODUCTION}

This study was conducted to determine the relative degree of pesticide contamination in four small drainage basins and to determine if pesticide residues were present in amounts that could be hazardous to humans or detrimental to aquatic 1ife. Each basin was chosen to represent a single land-use category--forested, general farming, residential, or orchard farming.

Selection of the four basins studied was based principally on the percentage of drainage area in the desired land-use category and the ease of collecting data during storms. The locations of the areas selected are shown in figure 1. The areas are (1) a $46.2 \mathrm{mi}^{2}\left(119.7 \mathrm{~km}^{2}\right)$ forested area situated in northern Clinton, eastern Potter, and western Lycoming Counties drained by Young Womans Creek; (2) a $15.0 \mathrm{mi}^{2}$ (38.8 km²) general-farming area in western Perry County drained by Bixler Run; (3) a $1.85 \mathrm{mi}^{2}\left(4.79 \mathrm{~km}^{2}\right)$ residential area in Dauphin County drained by an unnamed tributary of Spring Creek; and, (4) a $1.26 \mathrm{mi}^{2}\left(3.26 \mathrm{~km}^{2}\right)$ orchard-farming area in Adams County drained by an unnamed tributary of Latimore Creek.

Samples of bed material and water were collected periodically from each of the four areas from February 1969 to April 1971 and analyzed for chlorinated-hydrocarbon insecticides. Water samples only were analyzed for phenoxy-acid herbicides. Insecticide concentrations in local soils and fish (except in the orchard area) were determined once in each area. Data were collected also on streamflow, suspended-sediment concentration, and water chemistry.

\section{DATA COLLECTION}

Soil samples were collected from the top 3 inches (76 mm) (except in the orchard area) from different locations in each of the areas and composited into single samples for analysis. Soil samples from the orchard area were divided into three categories--from the area in open fields and woods, from the top 0.5 inch $(13 \mathrm{~mm})$ of orchard soil, and from the orchard soil 0.5 to 3 inches (13 to $76 \mathrm{~mm}$ ) deep.' Bed-material samples were collected from the top 2 inches $(51 \mathrm{~mm})$ of the streambed where fine material had been deposited.

Water samples were collected both during base-flow periods, when streams were normally clear, and during storms, when streams were highly turbid. Samples collected for suspended-sediment determinations were collected using standard depth-integrating sediment samplers (Guy and Norman, 1970), and samples for pesticide analyses were collected by wading and sampling, with a container of teflon or glass, at different depths throughout the vertical section. Samples for pesticide and suspended-sediment concentration were collected simultaneously. Pesticide analyses were performed on the whole water sample, including suspended sediment. 


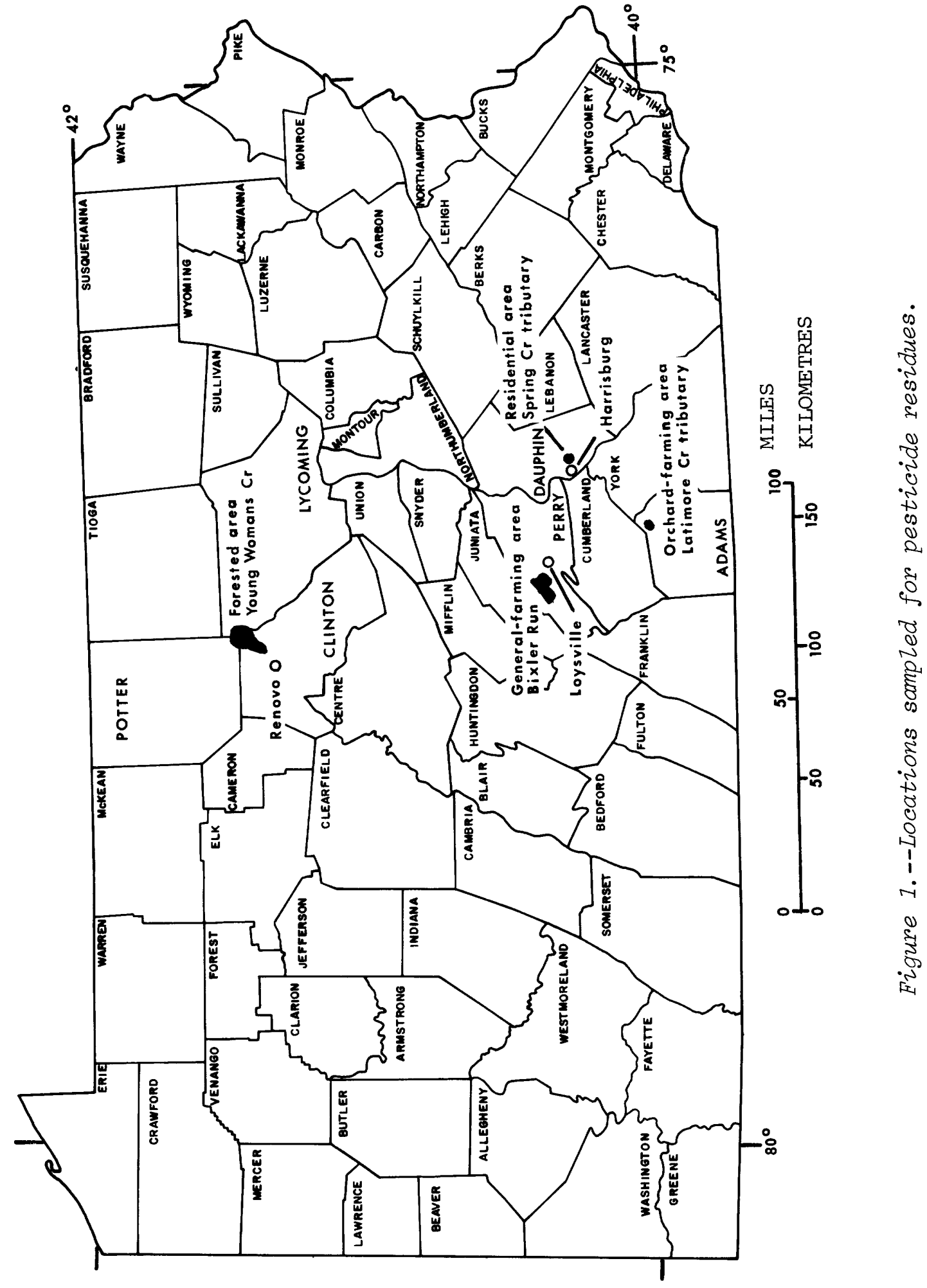


Fish samples were collected and separated according to species and age, and frozen. Analyses were performed on the whole fish.

Streamflow data were collected using the existing gaging station records for Young Womans Creek and Bixler Run and by using staff gages and storm hydrograph recorders installed during the study on the tributaries of Spring and Latimore Creeks.

The basic analytical procedures utilized in the pesticide analyses, and the pesticides which can be detected by these methods, have been described by Goerlitz and Brown (1972). A list of the pesticides that were detected is shown below. Subsequent tables show only those pesticides that were detected in each medium.

Insecticides:

Aldrin

Chlordane

DDD

DDE

DDT

dieldrin

endrin

Heptachlor epoxide

lindane $1,2,3,4,10,10$-hexachloro-1, 4, 4a , 5, 8, 8a-hexahydro1,4-endo-exo-5,8-dimethanonap thalene

$1,2,4,5,6,7,8,8$-octachlor-3a , 4, 7, 7a-tetrahydro4,7-methanoindane

1,1-dichloro-2,2-bis (p-chlorophenyl)ethane

1,1-dichloro-2,2-bis (p-chlorophenyl) ethylene

1,1,1-trichloro-2,2-bis ( $p$-chloropheny1) ethane

$1,2,3,4,10,10$-hexachloro $(6,7$-epoxy-1, 4, 4a , 5, 6, 7, 8, 8a -octahydro-1,4-endo-exo-5,8-dime thanonap thalene

$1,2,3,4,10,10$-hexachloro-6, 7-epoxy-1, 4, 4a , 5, 6, 7, 8, 8a -octahydro-1, 4-endo-endo-5,8-dimethanonap thalene

$1,4,5,6,7,8,8$-heptachloro-2, 3-epoxy-3a, 4, 7, 7a

-tetrahydro-4,7-methanoindan

$1,2,3,4,5,6$-hexachlorocyclohexane

Herbicides:

$2,4-D$

2,4-dichlorophenoxyacetic acid

silvex

2-(2,4,5-trichlorophenoxy) propionic acid

$2,4,5-\mathrm{T}$

2,4,5-trichlorophenoxyacetic acid. 


\section{DESCRIPTION OF STUDY AREAS}

\section{Forested}

Nearly 100 percent of the forested area, which is drained by Young Womans Creek, is State forest lands, in which there are light duty roads, hunting camps, and lodges. Water, chemical, and sediment discharge data have been collected since December 1964 at the Young Womans Creek gaging station near Renovo, as part of the U.S. Geological Survey's hydrologic bench-mark station network.

No known pesticide has been applied directly to this forested area. The nearest large-scale pesticide application was in 1965, when a part of the Kettle Creek basin that is adjacent to the Young Womans Creek basin on the north was aerially sprayed with DDT at the rate of 0.5 pound per acre $(0.5 \mathrm{~kg}$ per ha) for the control of fall cankerworm.

\section{Genera1 Farming}

The general-farming area, which is drained by Bixler Run, supports dairy farms typical of those located in the Valley and Ridge section of the State. Nearly all the crops grown, primarily corn, oats, mixed hay, and alfalfa, are used as feed for dairy cattle. Water, chemical, and sediment-discharge records have been collected since 1954 at the Bixler Run gaging station near Loysville.

Pesticides are used, especially for weed control in corn and insect control in alfalfa, but application rates and quantities were not determined.

\section{$\underline{\text { Residential }}$}

The residential area is in Dauphin County east of Harrisburg. The land is used primarily for suburban housing in $0.25-$ to 1 -acre $(0.1$ to $0.4 \mathrm{ha}$ ) 1ots. Pesticides are used to control insects and diseases on trees and shrubbery, and to control weeds, undesirable grasses, and insects in lawns. Application rates vary greatly from house to house and year to year. A random survey of homeowners in this area indicated that herbicides, usually applied with a fertilizer, are used more frequently than insecticides.

Spring Creek tributary, which drains this area, occasionally received domestic sewage during storms. This sewage, in addition to overland runoff during storms, may be a source of some of the pesticide residues found in the stream. Pesticides enter the sewers as a result of homeowners washing their spraying equipment or disposing of pesticides directly into sewers. 


\section{Orchard Farming}

Orchards occupy nearly 70 percent of the area drained by Latimore Creek tributary at the sampling location. Apples are the major crop, but cherries and peaches are also grown.

Pesticide applications for most apples begin in April and continue almost daily, covering the entire orchard area in about a 1-week period. Spraying is discontinued 2-3 weeks before harvest in September or October. Pesticides are applied mainly for the control of insects and fungus; however, small quantities are used to control rodents and limit the growth of grass and weeds. Most spraying is done by the individual farmer using tractor-towed orchard sprayers equipped with fans to propel the pesticide mist to the interior areas of the trees. Dieldrin and endrin were the only chlorinated-hydrocarbon insecticides applied during the period of this study. Exact records of the pesticides used in previous years are not available; however, the operator of the orchards has not used DDT for several years.

\section{OCCURRENCE OF PESTICIDES}

DDT or one of its metabolites (alteration products) was found in a11 areas and in each medium sampled except for soil samples in the forested area. Dieldrin was the next most commonly detected insecticide. Figure 2 shows where and in which media insecticides were detected. It does not indicate the frequency or magnitude at which insecticides were detected.

One or more of the herbicides--2,4,-D, silvex, or 2,4,5-T--was detected at least once in each stream. No analyses were performed for herbicides in soil, bed-material, or fish samples.

\section{In Soils}

Results of insecticide analyses of composited soil samples are shown on table 1. Highest insecticide concentrations were detected in soils from the orchard area. The samples were separated into three composite groups, as previously described, because higher concentrations were anticipated in this area than in the others. The combined concentration of DDT and its metabolites in the top 0.5 inch $(13 \mathrm{~mm})$ of orchard soil was $40,000 \mu \mathrm{g} / \mathrm{kg}$ (micrograms per kilogram). The calculated concentration of DDT and its metabolites in the top 3 inches (76 mm) of orchard-area soil was $14,000 \mu \mathrm{g} / \mathrm{kg}$, and corresponding values for the residentialand general-farming area solls were $55 \mu \mathrm{g} / \mathrm{kg}$ and $1.7 \mu \mathrm{g} / \mathrm{kg}$, respectively. No insecticide residues were found in forested-area soil samples.

The high concentration of DDT and its metabolites found in the top 0.5 inch $(13 \mathrm{~mm}$ ) of orchard soil (even though DDT has not been used for several years), indicates that residues of this insecticide remain primarily in the uppermost soil layers, associated with organic material and clay-size soil particles. 

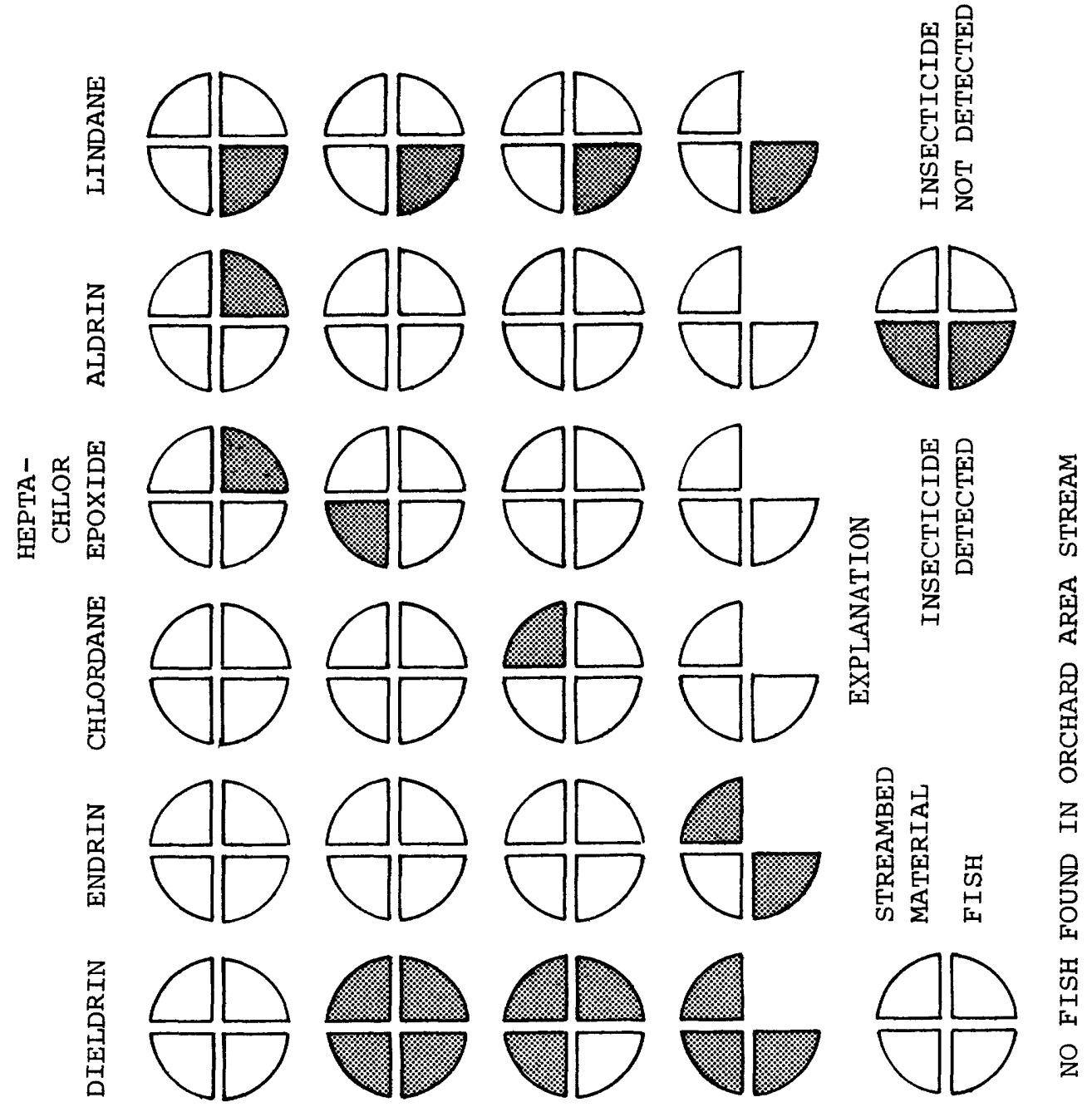

是䀺
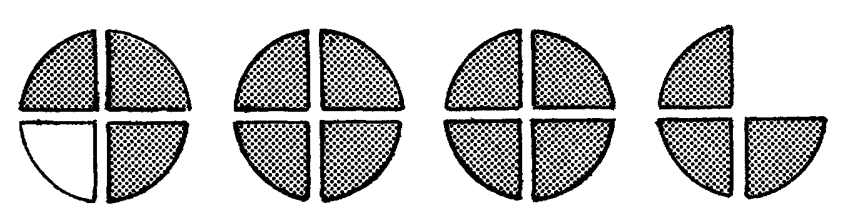

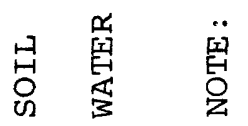

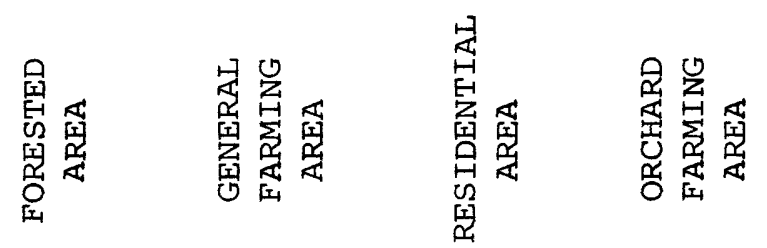

Figure 2.--Occurrence of insecticides in soil, bed-material, water, and fish samples collected from different land-use areas. 


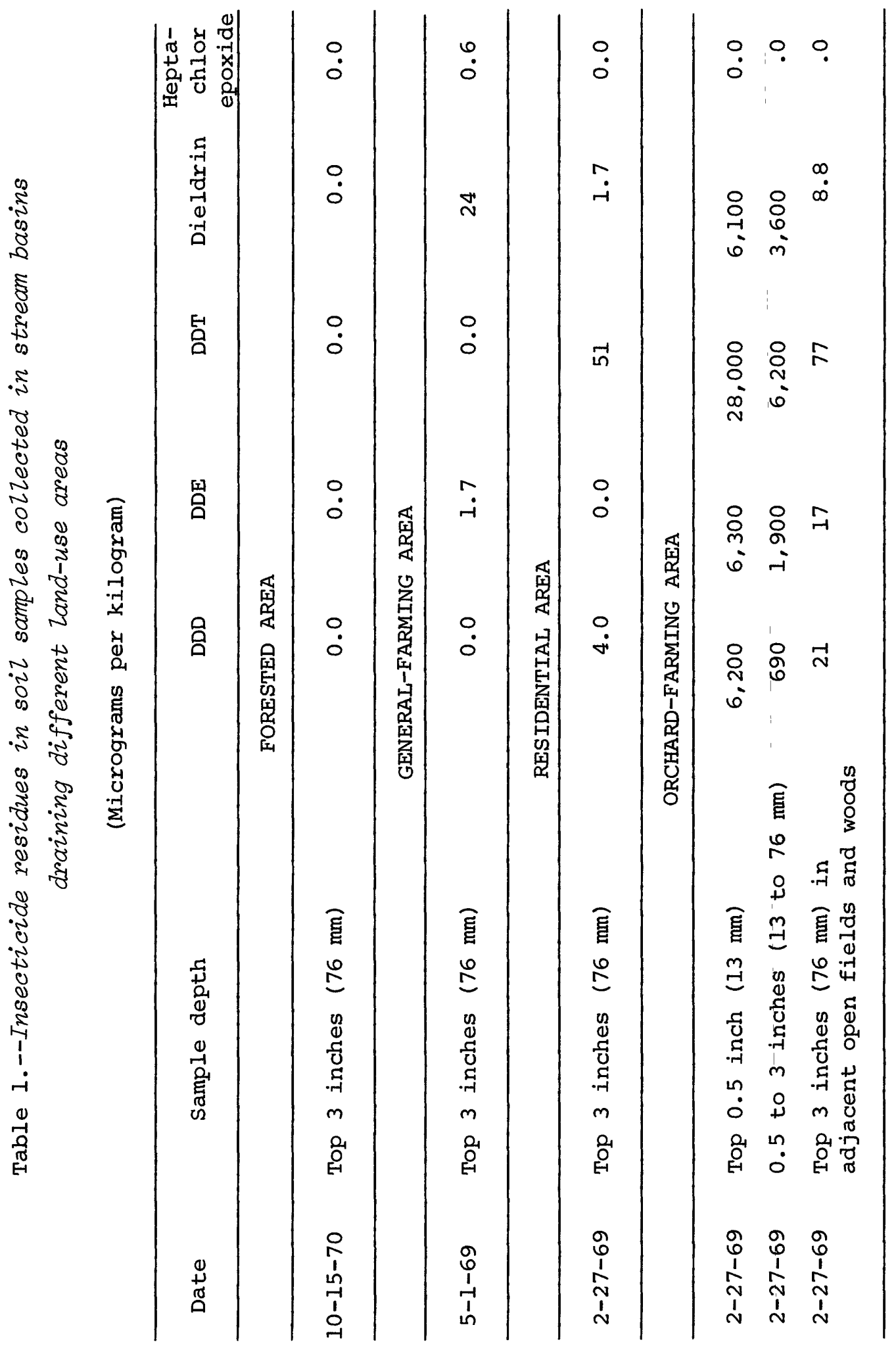




\section{In Bed Material}

Bed-material samples were collected on at least four occasions from each area and analyzed for the presence of insecticides. The results of these analyses are given in table 2. The observed ranges in the concentration of DDT and its metabolites from each of the four basins are shown in figure 3 . Lowest concentrations were observed in the streams draining the forested and general-farming areas, and highest in the streams draining the residential and orchard areas. The bed-material sample collected from Spring Creek tributary (residential area) on October 15, 1970, showed $5,900 \mu \mathrm{g} / \mathrm{kg}$ of DDT. This may reflect a slugdischarge, possibly through the sewer system during a recent storm. Separate sanitary and storm sewers were installed within the residential area during the study period but were not fully operational until after its completion. Prior to completion of the separate sewer system, residential sewage was flushed by direct runoff through storm sewers into Spring Creek tributary.

One bed-material sample, typical of the samples collected for insecticide analysis, was collected at each area for size analysis. Particlesize distributions for these samples are shown below. None of the samples contained any material larger than sand although the bed-materials in all except the residential-area stream are predominantly cobble sized.

\begin{tabular}{|c|c|c|c|}
\hline & $\begin{array}{c}\text { Sand } \\
\frac{\%}{0}\end{array}$ & $\begin{array}{c}\text { Silt } \\
\% \\
\end{array}$ & $\begin{array}{c}\text { Clay } \\
\% \\
\end{array}$ \\
\hline Forested area......... & 63 & 24 & 13 \\
\hline General-farming area........ & 73 & 12 & 15 \\
\hline Residential area.......... & 53 & 28 & 19 \\
\hline Orchard-farming area....... & 63 & 24 & 13 \\
\hline
\end{tabular}

\section{In Water}

More than 80 water samples (table 3) were analyzed for pesticide concentrations. Twenty percent were collected during base-flow periods, when sediment concentrations were 1ow; the remainder were collected during storms, when sediment concentrations were high. It was anticipated that pesticide residues observed during storm runoff would be higher than during base flow due to the increased suspension of sediment and organic detritus with which pesticides are associated.

Very low pesticide concentrations were observed in the four baseflow and six storm-runoff samples collected from Young Womans Creek. Pesticides were detected in only one base-flow and one storm-runoff sample. Bixler Run, like Young Womans Creek, showed very low concentrations. Pesticides were detected in only 1 of 4 base-flow samples and in 7 of 10 storm-runoff samples. 
Table 2.--Insecticide residues in bed-material scomples collected from streams draining different land-use areas

(Micrograms per kilogram)

\begin{tabular}{|c|c|c|c|c|c|c|}
\hline Date & Chlordane & DDD & $\mathrm{DDE}$ & $\mathrm{DDT}$ & Dieldrin & Endrin \\
\hline \multicolumn{7}{|c|}{ FORESTED AREA } \\
\hline $6-10-68$ & 0 & 0.5 & 0.1 & 0.5 & 0.0 & 0.0 \\
\hline $11-27-68$ & 0 & .5 & .0 & .5 & .0 & .0 \\
\hline $5-20-69$ & 0 & .0 & .6 & .0 & .0 & .0 \\
\hline $7-10-69$ & 0 & .0 & .0 & .0 & .0 & .0 \\
\hline $10-2-69$ & 0 & .2 & .0 & .0 & .0 & .0 \\
\hline $11-18-70$ & 0 & .0 & .0 & .0 & .0 & .0 \\
\hline $4-15-71$ & 0 & .8 & .9 & .5 & .0 & .0 \\
\hline Mean & 0 & .3 & .2 & .2 & .0 & .0 \\
\hline Median & 0 & .2 & .0 & .0 & .0 & .0 \\
\hline \multicolumn{7}{|c|}{ GENERAL-FARMING AREA } \\
\hline $2-27-69$ & 0 & 0.0 & 0.0 & 0.0 & 0.5 & 0.0 \\
\hline $7-9-69$ & 0 & .0 & .0 & .0 & .0 & .0 \\
\hline $10-15-70$ & 0 & .0 & .0 & .0 & .0 & .0 \\
\hline $4-13-71$ & 0 & .4 & .5 & .5 & .3 & .0 \\
\hline Mean & 0 & .1 & .1 & .1 & .2 & .0 \\
\hline Median & 0 & .0 & .0 & .0 & .0 & .0 \\
\hline \multicolumn{7}{|c|}{ RESIDENTIAL AREA } \\
\hline $4-30-69$ & 0 & 7.4 & 6.9 & 9.1 & 0.0 & 0.0 \\
\hline $7-8-69$ & 0 & 1.1 & 1.0 & 1.5 & .0 & .0 \\
\hline $8-28-69$ & 0 & 1.0 & .0 & 2.5 & $a / T$ & .0 \\
\hline $10-15-70$ & 0 & 47 & 10 & 5,900 & .0 & .0 \\
\hline $4-13-71$ & 250 & 5.2 & 11 & 5.7 & .2 & .0 \\
\hline Mean & 50 & 12 & 5.8 & 1,200 & .0 & .0 \\
\hline Median & 0 & 5.2 & 6.9 & 5.7 & .0 & .0 \\
\hline \multicolumn{7}{|c|}{ ORCHARD-FARMING AREA } \\
\hline $2-27-69$ & 0 & 59 & 30 & 53 & 0.0 & 0.0 \\
\hline $4-30-69$ & 0 & 37 & 23 & 50 & 10 & .0 \\
\hline $7-8-69$ & 0 & 19 & 14 & 31 & .0 & .0 \\
\hline $10-15-70$ & 0 & 190 & 41 & 54 & 7.7 & 55 \\
\hline $4-13-71$ & 0 & 230 & 60 & 37 & 10 & 120 \\
\hline Mean & 0 & 110 & 34 & 45 & 5.7 & 35 \\
\hline Median & 0 & 59 & 30 & 50 & 7.7 & .0 \\
\hline
\end{tabular}

a/ Trace. 


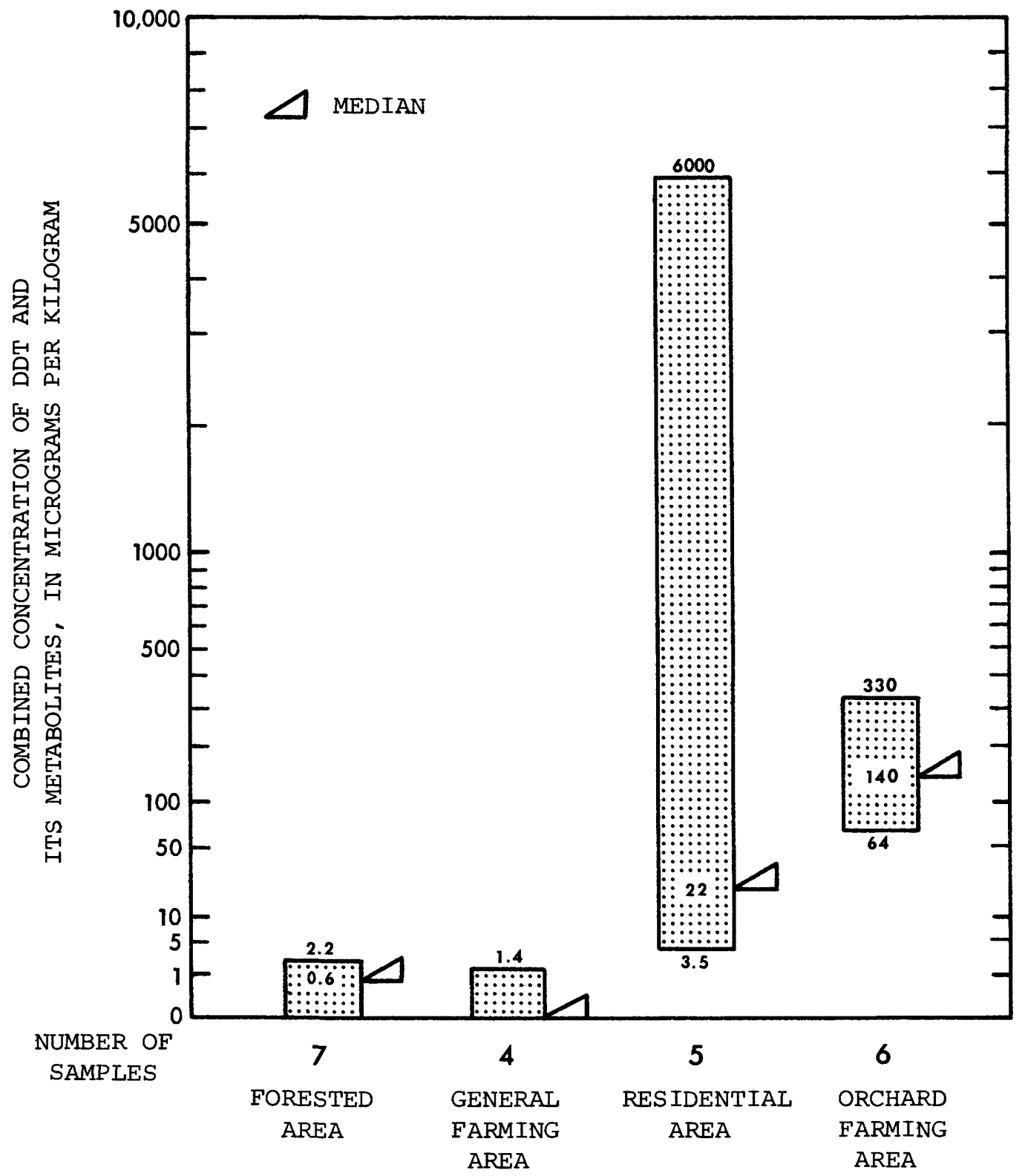

Figure 3.--Range in concentration of DDT and its metabolites in bed-material samples collected from streams draining different Zand-use areas. 


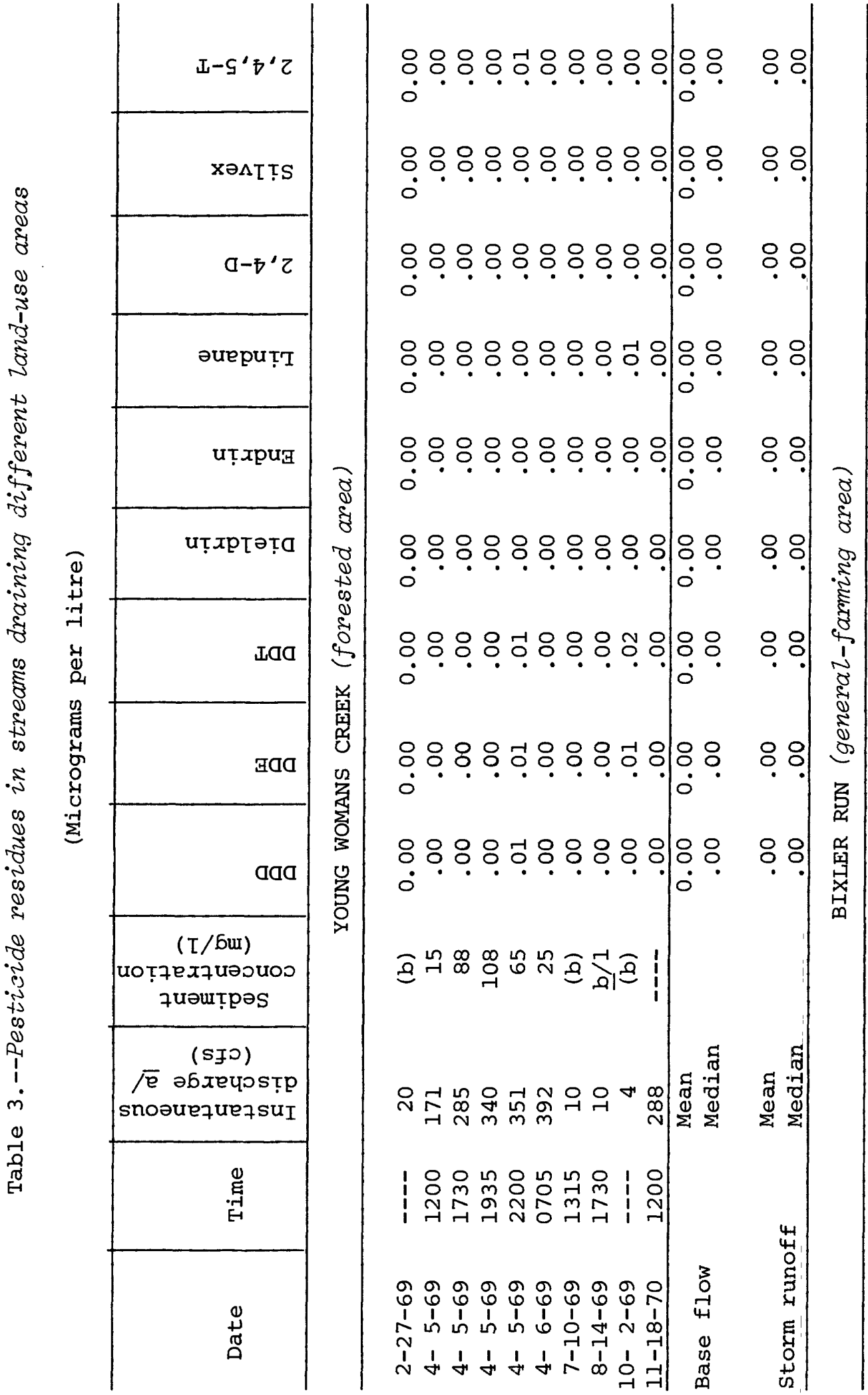

웅ํํ유유.

ํํㅇํํํํํำ

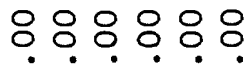
$\circ$

:ㅇ: : : : $\dot{0}$

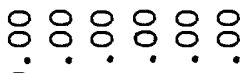
$\dot{0}$

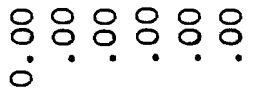

ঃํํํํ․

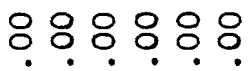
$\dot{0} \cdot . \cdot \cdot$

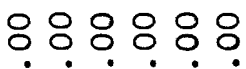
$\circ \cdot \cdot \cdot$

aㅇำ $\stackrel{\infty}{\sigma} \widehat{a} \mid \hat{a}$

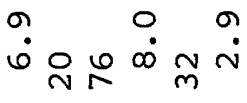

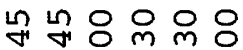

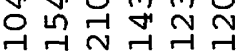

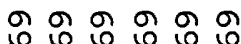

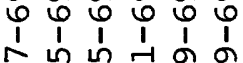
$\begin{array}{llll}1 & 1 & 1 & 1\end{array}$

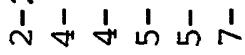




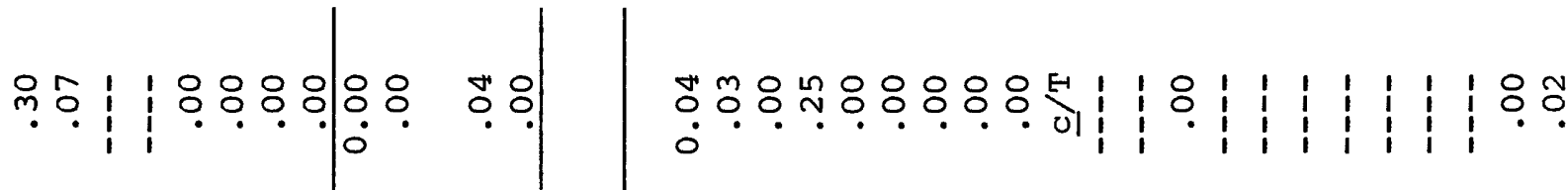

ㅇ:

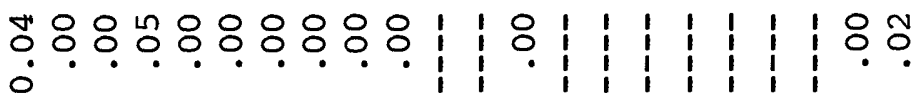

성요:

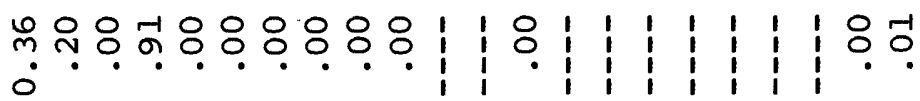

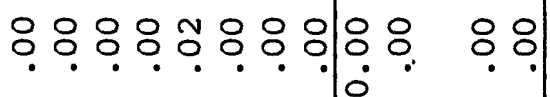

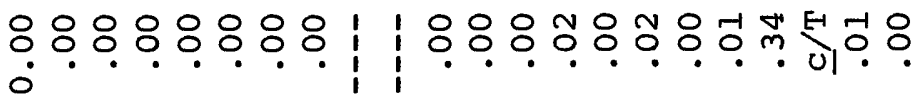

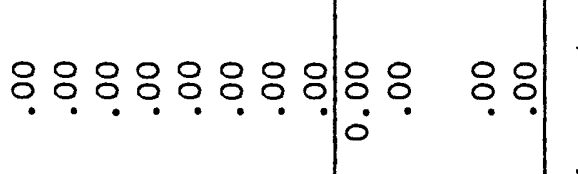

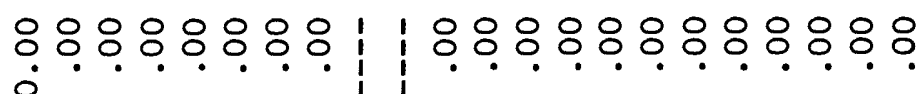

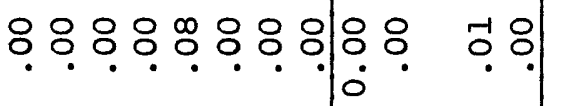

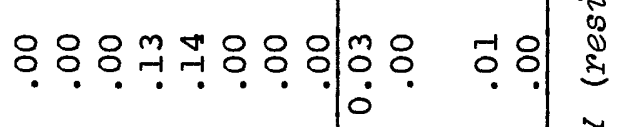

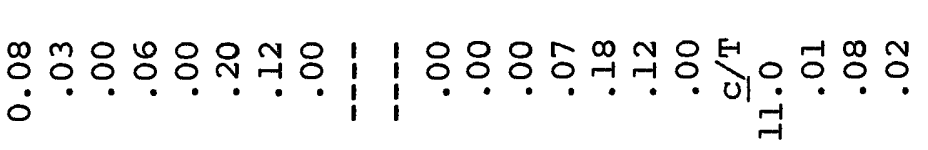

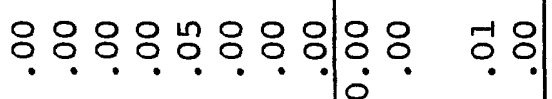

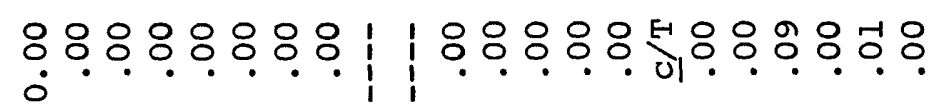

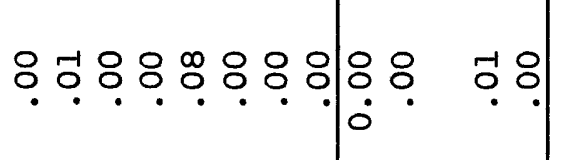

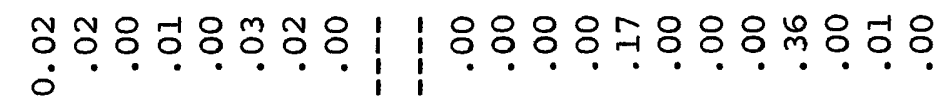

오ำกั

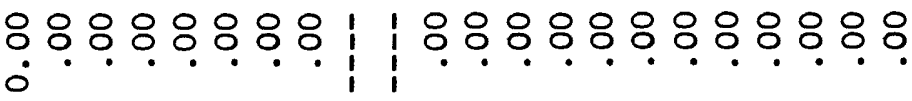

웅은은

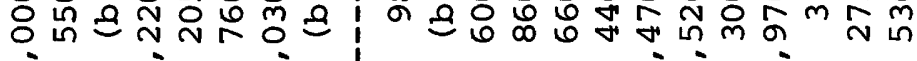
i i i i i i i

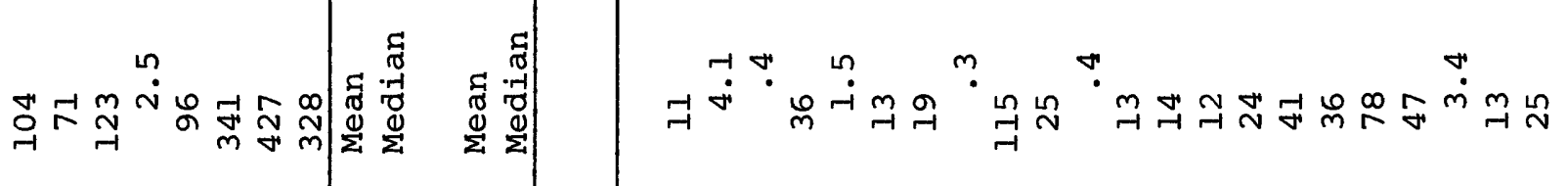

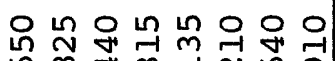

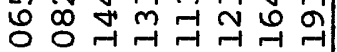

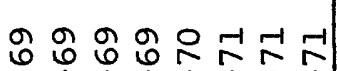

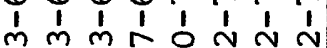

N N N N

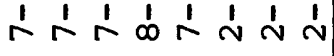

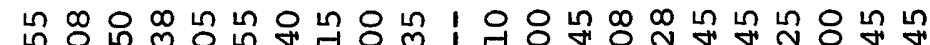
r

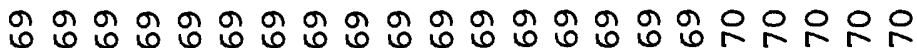

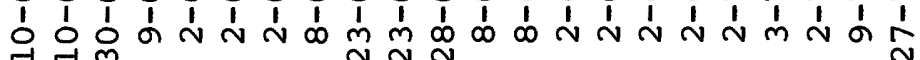

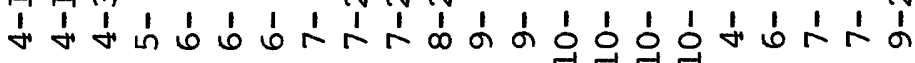




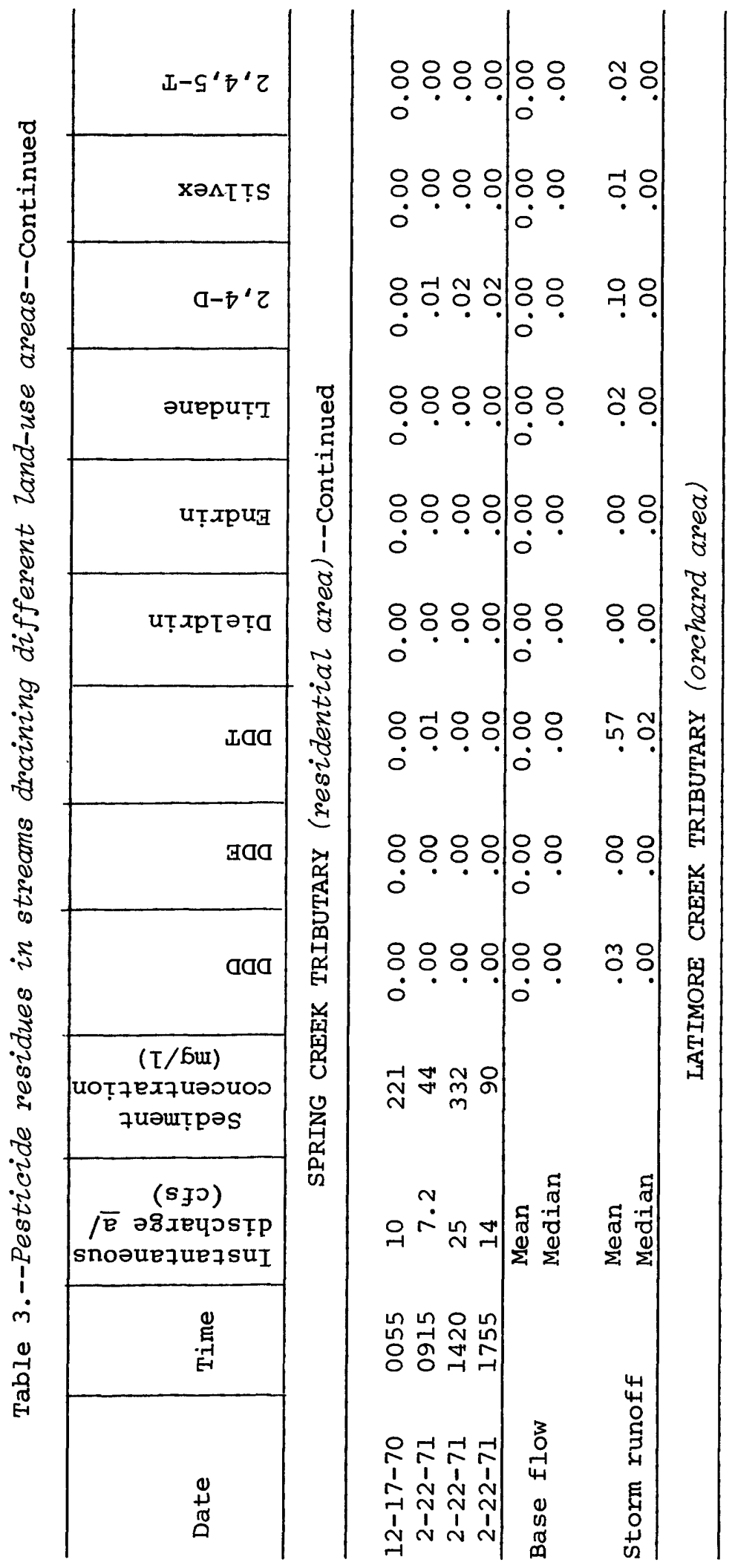

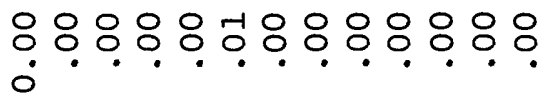

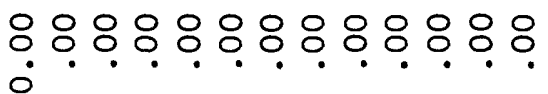

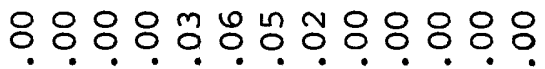
$\circ$

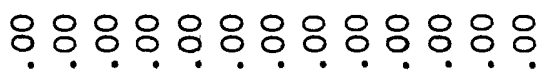
$\circ$

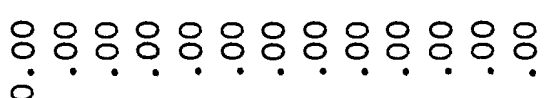

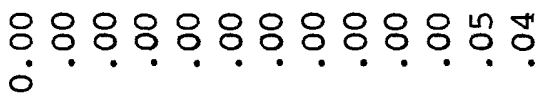

:

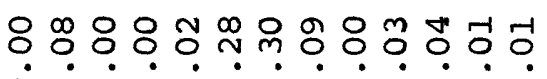
०.

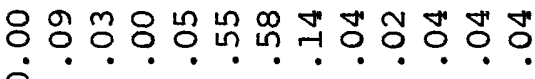

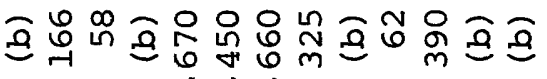
i i

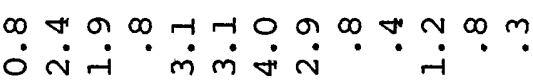

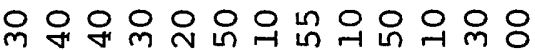

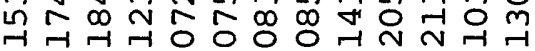

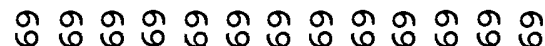

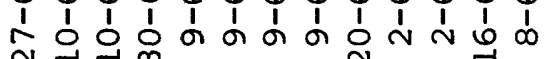

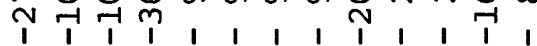

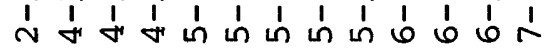




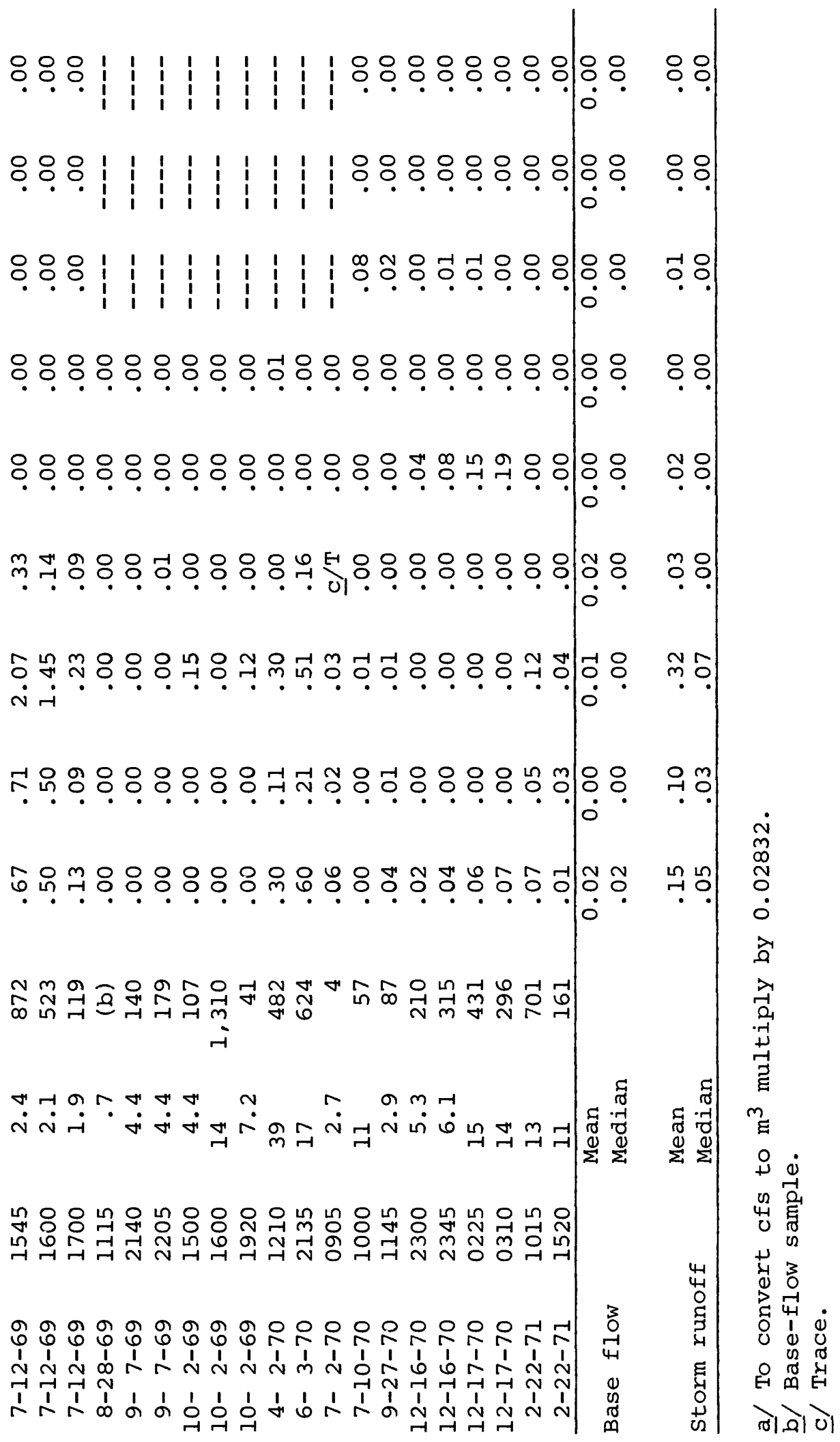


Spring Creek tributary was sampled 3 times during base flow and 23 times during storms. Pesticides were not detected in any of the baseflow samples. However, nearly all of the storm-runoff samples contained pesticide residues. The highest observed concentration of a single pesticide residue in any water sample was the $11.0 \mathrm{\mu g} / 1$ (micrograms per litre) of DDT found in a storm-runoff sample collected at this sampling site in June 1970.

Latimore Creek tributary was sampled 6 times during base flow and 27 times during storms. Pesticides were detected in three of the base-flow and in all but two of the storm-runoff samples. The highest observed concentration of a single pesticide detected at this sampling site was the $2.50 \mu \mathrm{g} / 1$ of DDT found in a storm-runoff sample collected on May 9, 1969.

The maximum, minimum, and median concentrations of DDT and its metabolites observed in the water samples analyzed from each of the four streams are illustrated in figure 4. This figure shows that the lowest observed concentrations occurred in the forested and general-farming areas, while the highest observed concentrations occurred in the residential and orchard areas. The combined concentration of $11.4 \mu \mathrm{g} / 1$ of DDT and its metabolites observed in Spring Creek tributary on June 3, 1970, may have resulted from a slug discharge. Subsequent samples show about the same concentrations as previously observed.

None of the pesticide residues detected in the water samples exceeded the maximum permissible concentration (table 4) recommended by the U.S. Public Health Service (1969). The highest combined concentration of DDT and its metabolites detected in water samples was $11.4 \mu \mathrm{g} / 1$, or 27 percent of the maximum permissible concentration. This concentration was found in a sample collected from Spring Creek tributary on June 3, 1970. The highest combined concentration in Latimore Creek tributary was $3.45 \mu \mathrm{g} / 1$, or 8 percent of the maximum permissible concentration, in a sample collected on July 12, 1969.

Endrin was detected at a concentration of $0.19 \mu \mathrm{g} / 1$, or 19 percent of the maximum permissible concentration, in a water sample collected in Latimore Creek tributary on December 17, 1970. No other pesticides were detected in excess of 2 percent of the recommended maximum permissible concentration for pesticides in public-water supplies.

\section{In Fish}

Fish were collected in March 1970 from three of the four streams investigated. An attempt was made to collect fish from all streams. No fish were found during this sampling period in Latimore Creek tributary, although fish had been observed the previous fall. The fish were separated by species and age, except for the blacknose dace, and analyzed for insecticides. Results of the analyses appear in table 5 . 


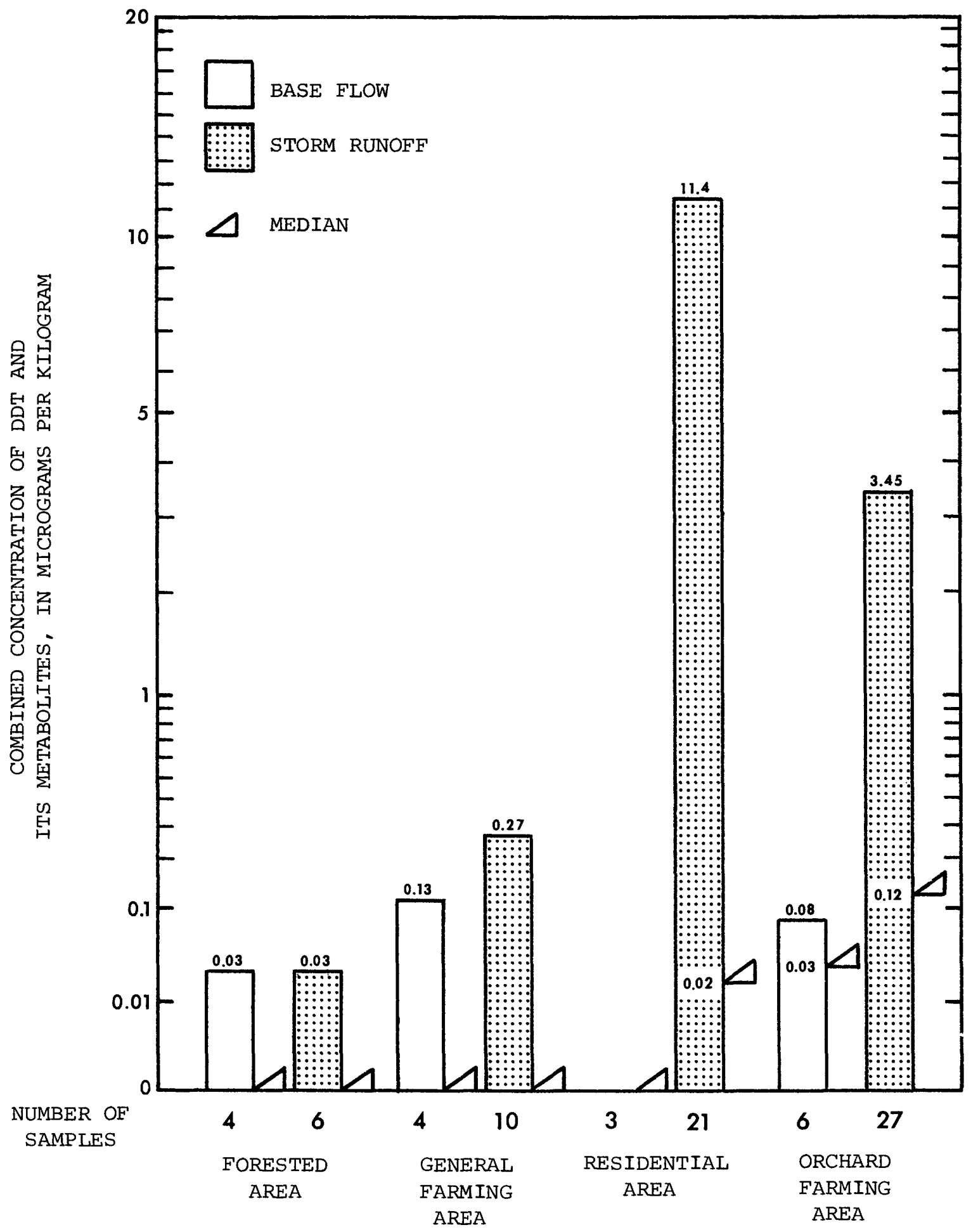

Figure 4.--Range in concentration of DDT and its metabolites in streams draining different land-use areas. 
Table 4.--Recommended maximum permissible pesticide concentrations in drinking-water supplies, U.S. Public Health Service

\begin{tabular}{|c|c|}
\hline Pesticide & $\begin{array}{l}\text { Maximum permissible } \\
\text { concentration, in } \\
\text { micrograms per litre a/ }\end{array}$ \\
\hline Endrin & 1 \\
\hline Aldrin & 17 \\
\hline Dieldrin & 17 \\
\hline Lindane & 56 \\
\hline Toxaphene & 5 \\
\hline Heptachlor & 18 \\
\hline Heptachlor epoxide & 18 \\
\hline DDT & 42 \\
\hline Chlordane & 3 \\
\hline Methoxychlor & 35 \\
\hline $\begin{array}{l}\text { Total organophosphorus and } \\
\text { carbamate compounds b/ }\end{array}$ & 100 \\
\hline $\begin{array}{l}2-4-5-T P \\
2,4,5-T \\
2,4-D \subseteq\end{array}$ & $\left\{\begin{array}{l}\text { Individual limits }=100 \mu \mathrm{g} / 1 \text {; Sum } \\
\text { of any combination of chlorinated } \\
\text { phenoxy alkyl pesticides }=100 \mu \mathrm{g} / 1\end{array}\right.$ \\
\hline
\end{tabular}

a/ For long-term exposure.

b/ Expressed in terms of parathion equivalent cholinesterase inhibition.

c/ Short period limit only: 2 to 3 days, no more than once or twice a year.

Only one compound, DDE, was found in each of the fish samples. It was observed in approximately equal concentrations in the same species of fish from Young Womans Creek and Bixler Run, and in concentrations approximately 10 times greater in the same species from Spring Creek tributary. The highest concentration of DDT and its metabolites observed in fish samples was $590 \mu \mathrm{g} / \mathrm{kg}$, or about 12 percent of the recommended maximum $(5,000 \mu \mathrm{g} / \mathrm{kg}$ in the edible portion) for food fish (U.S. Public Health Service, written commun., 1974). 
Table 5.--Pesticide residues in fish samples collected from streams draining different Zand-use areas

(Micrograms per kilogram)

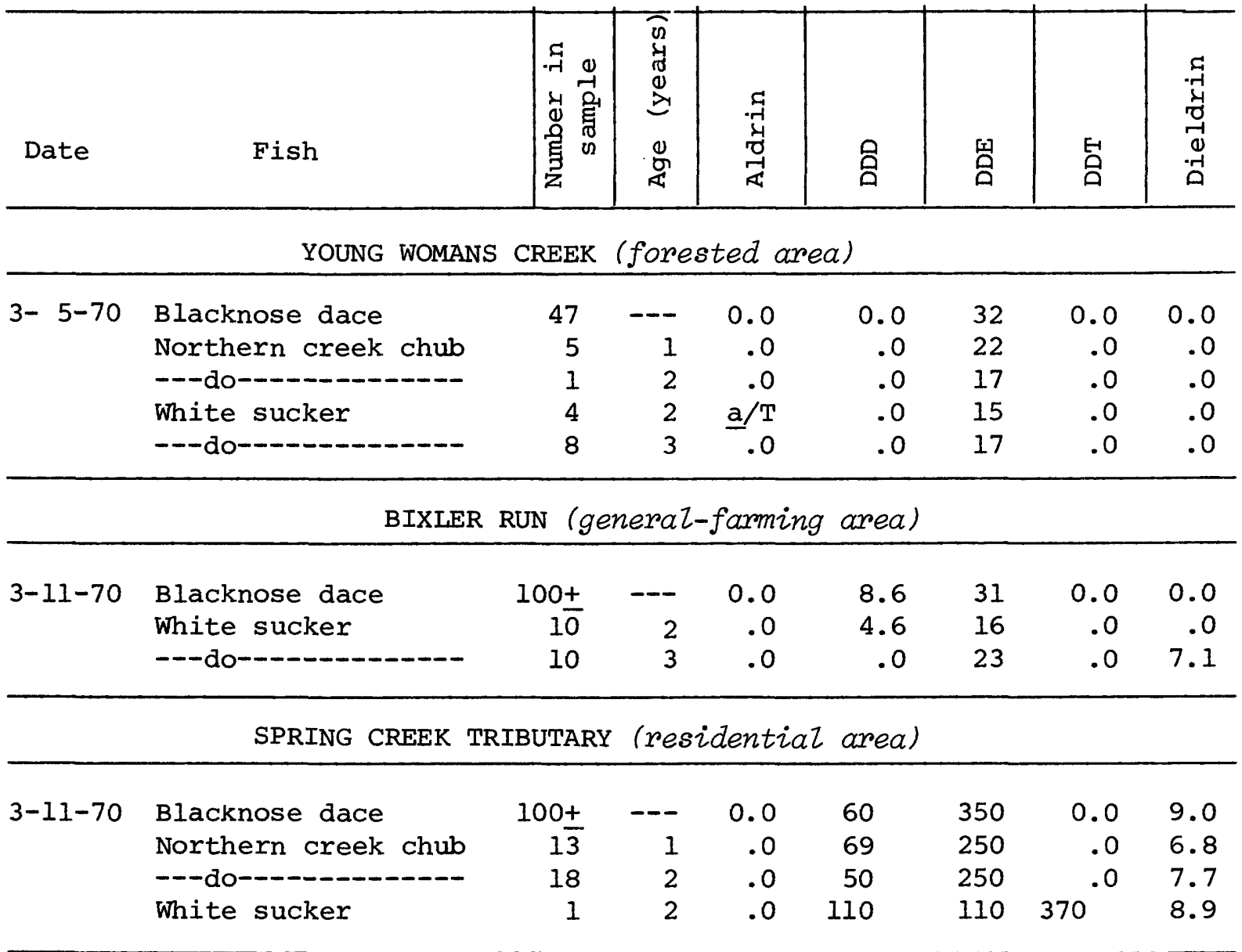

a/ Trace. 


\section{RELATION OF PESTICIDES TO SUSPENDED SEDIMENT}

Correlation between suspended-sediment concentration and the combined concentration of DDT and its metabolites was examined for each site. No correlation was apparent for either Young Womans Creek or Bixler Run, where only very low concentrations of pesticides were found. The general relationship, showing low pesticide concentrations at base flow and high concentrations only when suspended-sediment concentrations were relatively high, was apparent for Spring Creek tributary, but considerable scatter was observed. A fair correlation was found for Latimore Creek tributary, where combined concentration of DDT and its metabolites ranged from 0 to $3.45 \mu \mathrm{g} / 1$, with a corresponding range in suspended-sediment concentrations from $50 \mathrm{mg} / 1$ to more than $2,000 \mathrm{mg} / 1$. Figure 5 shows this correlation. $\mathrm{DDT}$ is no longer used in the orchards, and the only source of DDT is from residues in the soil; therefore, input to the stream would be expected to reflect storm intensity, erosion, and sediment transport.

Analyses of particle-size distribution were made for five Latimore Creek tributary suspended-sediment samples that were collected simultaneously with samples analyzed for pesticide residues. These data are shown below with the computed clay concentrations and the combined concentration of DDT and its metabolites found in corresponding pesticide samples. Except for the sample collected December 17, 1970, the concentration of DDT and its metabolites shows a better correlation with the computed clay concentration than with the total suspended-sediment concentration.

\begin{tabular}{|c|c|c|c|c|c|c|}
\hline \multirow[b]{2}{*}{ Date } & \multirow[b]{2}{*}{$\begin{array}{c}\text { Sand } \\
\quad 8 \\
\end{array}$} & \multirow[b]{2}{*}{$\begin{array}{c}\text { Silt } \\
\frac{8}{8} \\
\end{array}$} & \multirow[b]{2}{*}{$\begin{array}{c}\text { Clay } \\
\quad \frac{8}{8} \\
\end{array}$} & \multicolumn{2}{|c|}{$\begin{array}{l}\text { Suspended- } \\
\text { sediment } \\
\text { concentration }\end{array}$} & \multirow{2}{*}{$\begin{array}{c}\mathrm{DDT} \text { and } \\
\text { metabolites } \\
\mu \mathrm{g} / 1 \\
\end{array}$} \\
\hline & & & & $\begin{array}{l}\text { Total } \\
\mathrm{mg} / 1\end{array}$ & $\begin{array}{l}\text { Clay } \\
\mathrm{mg} / 1\end{array}$ & \\
\hline $4-10-69$ & 1 & 53 & 46 & 166 & 76 & 0.40 \\
\hline $7-12-69$ & 0 & 29 & 71 & 523 & 371 & 3.45 \\
\hline $4-2-70$ & 34 & 46 & 20 & 482 & 96 & .71 \\
\hline $6-3-70$ & 7 & 50 & 43 & 624 & 269 & 1.32 \\
\hline $12-17-70$ & 11 & 65 & 24 & 431 & 103 & .06 \\
\hline
\end{tabular}

\section{EFFECTS OF PESTICIDES ON AQUATIC LIFE}

Both the residential and orchard area streams investigated during this study occasionally contain instantaneous pesticide residue concentrations that might be toxic to some fish exposed for 96 hours (U.S. Fish and Wildife Service, 1963, 1964, 1965). The maximum concentrations observed in these streams occurred during storms when observed suspended-sediment concentrations were also at a maximum, and probably never persisted for more than a half hour. However, pesticide concentrations safe for aquatic life under conditions of continuous exposure are considerably 


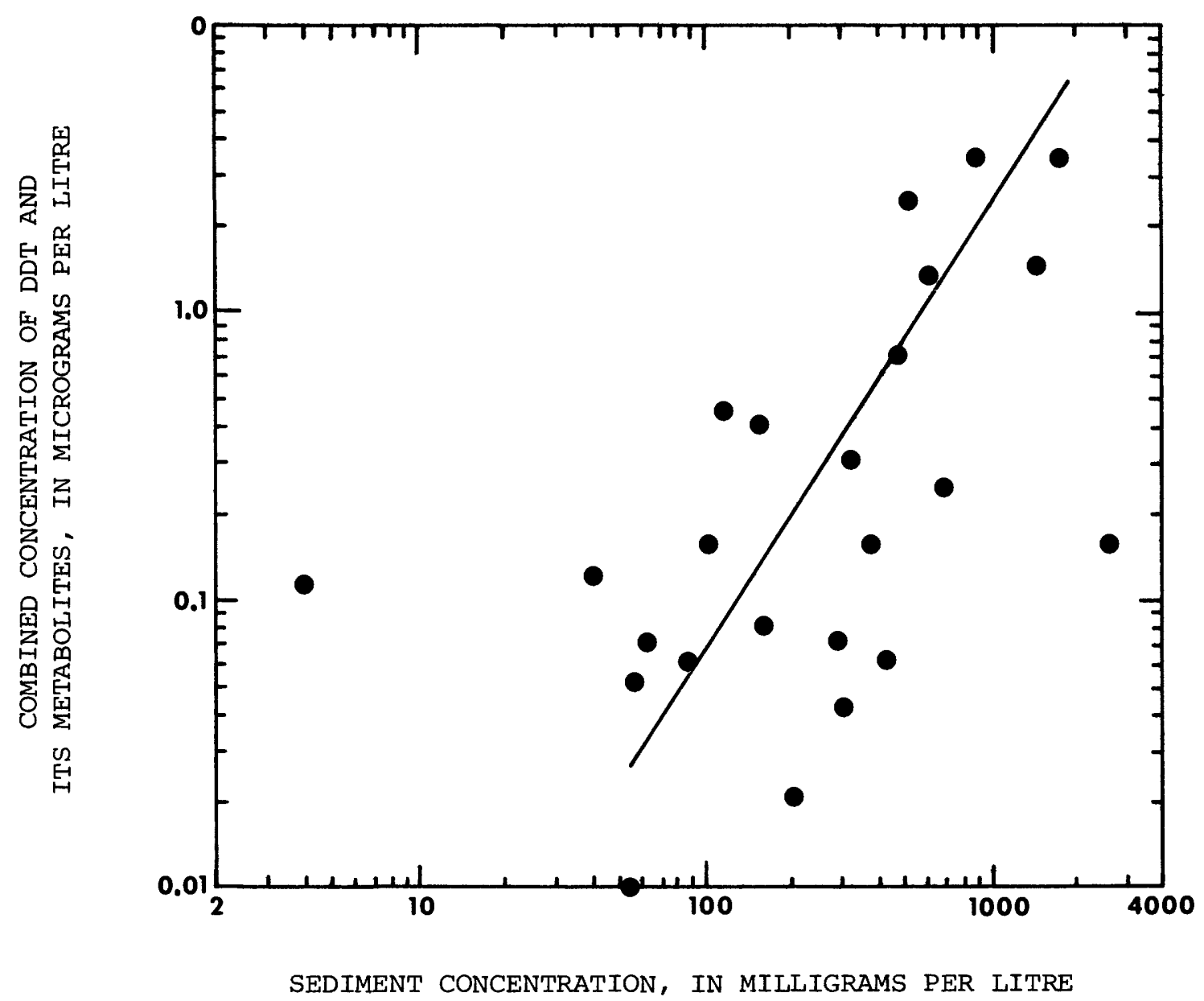

Figure 5.--Correlation between suspended-sediment concentration and combined concentration of DDT and its metabolites in Latimore Creek tributary. 
less than the 96-hour concentrations (Tarzwe11, 1959). The effects of these exposures, in addition to chronic low-level exposure, are practically impossible to evaluate, but it appears possible that there may occasionally be some damage to fish populations in both the residential and orchard area streams.

Aquatic insects are more susceptible than fish to chlorinated-hydrocarbon insecticides. Damage to insect populations probably occurs in both the residential and orchard area streams, because these insects spend part of their life cycle in the streambed where pesticide concentrations are higher than in the water. An attempt was made to collect fish in the orchard stream, and the streambed was examined for macroinvertebrates, but neither were found. The lack of fish food, rather than a direct fishki11, may account for the fact that no fish were found. However, pesticides may occasionally be discharged in highly concentrated slugs that could decimate both insect and fish populations. Since it is unlikely that any of the samples were collected exactly at the time of highest residue concentration, higher concentrations than those observed may have occurred.

\section{DISCUSSION}

Pesticide residues were detected in Young Womans Creek even though none were detected in soil of the basin. Also, lindane was detected in all four streams but in no other environmental component. A possible explanation for this is that the detection limits for pesticides in water are lower than the detection limits in other media.

Higher DDT concentrations were observed in one bed-material sample and one storm-runoff sample from Spring Creek tributary than in any of the samples from Latimore Creek tributary, even though DDT concentrations in the soil were much lower in the residential area drained by Spring Creek than in the orchard area, drained by Latimore Creek tributary. Slug discharges, possibly through the sewer system, may account for the occurrence of high concentrations. High DDT concentrations in the Spring Creek tributary may also result from storm-runoff following recent applications of DDT in the residential area. No DDT has been used in the orchard area for several years; thus, the only source for DDT in Latimore Creek tributary is from residues in the orchard soils. Slug discharges of other pesticides may sometimes occur in the orchard area because some part of the orchards is sprayed almost daily and summer storms sometimes occur unexpectedly, washing off recently applied pesticides.

The high DDT concentrations observed in soil samples collected in the orchard area were not reflected in bed-material or storm-runoff samples. This suggests that most DDT remains fixed in the soil and is not easily leached. Soil that enters the stream system as sediment 
appears to be the dominant transport mechanism of pesticide residues, indicating that effective erosion control could decrease the pesticide load in streams.

Analysis of bed-material or storm-runoff samples appears to be the most expedient and definitive way to determine the relative degree of pesticide contamination in a stream. Base-flow samples contain little or no pesticide residues regardless of the residues present in basin soils. Fish, though they may be good indicators of pesticide contamination, are more difficult to collect and analyze.

There may occasionally be some damage to insect and fish populations in Spring Creek tributary and Latimore Creek tributary, but no water or fish samples contained pesticides in excess of the U.S. Public Health Service recommended maximum permissible concentration for public water supplies or food fish.

\section{REFERENCES}

Goerlitz, D. F., and Brown, Eugene, 1972, Methods for analysis of organic substances in water: U.S. Geol. Survey Techniques WaterResources Inv., book 5, chap. A3, 40 p.

Guy, H. P., and Norman, V. W., 1970, Field methods for measurement of fluvial sediment: U.S. Geol. Survey Techniques. Water-Resources Inv., book 3, chap. C2, 59 p.

Tarzwe11, C. M., 1959, Pollutional effects of organic insecticides: Twenty-fourth North Am. Wildlife Conf. Trans., Mar. 2-4, 1959, p. 132-142.

U.S. Fish and Wildlife Service, 1963, Pesticide-wildlife studies--A review of Fish and Wildlife Service investigations during 1961 and 1962: U.S. Fish and Wildlife Service Circ. 167, 109 p.

1964, Pesticide-wildlife studies, 1963--A review of Fish and Wildlife Service investigations during the calendar year: U.S. Fish and Wildlife Service Circ. 199, $130 \mathrm{p}$.

1965, The effects of pesticides on fish and wildlife: U.S. Fish and Wildlife Service Circ. 226, 77 p.

U.S. Public Health Service, 1969, Manual for evaluating public drinking water supplies: U.S. Public Health Service Pub. 1820, 62 p. 